\title{
The Role of Religiosity in Explaining the Intention to use Islamic FinTech Amongst MSME Actors
}

\author{
Rifaldi Majid \\ Universitas Airlangga, Indonesia \\ Corresponding email: rifaldimajid@gmail.com
}

Article History

Received: May 30th, $2021 \quad$ Revised: July 26th, $2021 \quad$ Accepted: July 28th, 2021

\begin{abstract}
Islamic FinTech is growing rapidly and has become a new alternative of financing for micro, small, and medium enterprises (MSME) which are the backbone of the national economy. This study aims to examine the role of religiosity level of MSMEs actors on the intention to use Islamic FinTech. This research employed Partial Least Square - Structural Equation Modeling (PLSSEM) method. The data collected using an online questionnaire adapted from previous research, then distributed to 100 Indonesian MSME actors and analyzed using smart PLS. The main result indicated religiosity plays a positively significant role in explaining the intention to use Islamic FinTech. In addition, Perceived Usefulness (PU), Perceived Ease of Use (PEOU), and Subjective Norm (SN) were also found to be influential, while both, Attitude Toward Behavior (ATB) and Perceived Behavioral Control (PBC), have no significant effect on behavioral intention. This research implicates the need for collaboration between the Financial Services Authority (OJK) as the regulator with Islamic FinTech institutions to improve literacy, providing incentives, strengthening consumer data protection, as well as integrating the values from the religious anglein the concept and practice of FinTech product and services that are based on Islamic guideline in order to attract the users from MSME actors.
\end{abstract}

Keywords: MSMEs Actor's Intention; PLS-SEM; Islamic FinTech; Religiosity JEL Classification: L81, M51, 014

Type of Paper: Research Paper

@ IJIEF 2021 published by Universitas Muhammadiyah Yogyakarta, Indonesia All rights reserved

DOI: Web:

https://doi.org/10.18196/ijief.v4i2.11833 https://journal.umy.ac.id/index.php/ijief/article/view/11833

Citation:

Majid, R. (2021). The Role of religiosity in explaining the intention to use islamic fintech amongst MSME Actors. International Journal of Islamic Economics and Finance (IJIEF), 4(2), 207-232. DOI: 10.18196/ijief.v4i2.11833 
Majid The Role of Religiosity in Explaining the Intention to use Islamic FinTech Amongst MSME Actors

\section{Introduction}

\subsection{Background}

In the rapid development of information technology, FinTech has penetrated and become an alternative means of solutions from innovative financial service transactions as a solution of traditional banking, insurance, and asset management. FinTech is defined as an innovation in the use of digital technology to compete and at the same time to solve financial intermediation problems (Aaron, Rivadeneyra, \& Sohal, 2017; Fenwick, McCahery, \& Vermeulen, 2017). Compared to other types of financial institutions, the FinTech industry is among the fastest and largest-growing economic sectors (Chemmanur, Imerman, Rajaiya, \& Yu, 2020; Niswah, Mutmainah, \& Legowati, 2019) including FinTech which operates with sharia principles.

Islamic FinTech can become a large global industry, especially in the midst of the potential development of the world's Muslim population, which is estimated to reach $26.4 \%$ of the world's total population in 2030 (The World Bank, 2020), where Indonesia is predicted to be the country with the secondlargest Muslim population in the same year namely as many as 238 million people (Pew Research Center, 2011). Based on a report from the Global Islamic FinTech Report in 2021 published by DinarStandard, the market size of Islamic FinTech in Indonesia will reach \$ 2.9 Billion in 2020 and is predicted to reach \$ 8.3 Billion in 2025. Indonesia is ranked 4th after Saudi Arabia, Malaysia, and the United Arab Emirates as the country with the largest total volume of transactions with a total score of 66 Global Islamic FinTech Index (GIFT) which is an accumulation of 32 indicators covering 5 categories, namely Islamic FinTech market \& ecosystem, talent, regulation, infrastructure, \& capital (DinarStandard, 2021).

The rapid development of Islamic FinTech in Indonesia, apart from being driven by the legal protection of the Financial Services Authority (POJK) Number 77/POJK.01/ 2016 concerning Information Technology-Based Borrowing and Lending Services, is also due to support from the sharia-legal compliance side which refers to the fatwa of the National Sharia Council of the Indonesian Ulema Council (DSN-MUI) No.117/DSN-MUI/II/2018 regarding information technology-based financing services based on sharia principles. In the fatwa, Islamic FinTech or technology-based financing services with sharia principles is defined as the operation of financial services in accordance with sharia principles that bring together or connect a Financing Provider with a Financing Recipient whose purpose is to carry out financing transactions through an electronic system (DSN-MUI, 2018). 
Majid The Role of Religiosity in Explaining the Intention to use Islamic FinTech Amongst MSME Actors

The presence of Islamic FinTech is a momentum that opens great potential for new alternative financing in accordance with sharia principles outside the banking sector which is intended to increase transactions, fulfill market needs, and financial inclusion, both for individuals and especially for business actors, namely micro, small and medium enterprises (MSMEs) which are the backbone of the Indonesian economy. This is in line with the reality faced by MSMEs -which amount to 62.8 million (of which 98.7\% are micro-businesses) with a contribution to a Gross Domestic Product (GDP) of $57.8 \%$ in 2018 (Kementerian Koperasi dan Usaha Kecil Menengah, 2018) that are still struggling and faced with fundamental classic problems, namely limited capital and access to finance as well as business operational management such as low quality of human resources (HR), marketing capabilities, business networks, and market analysis, as well as limited infrastructure and use of information technology and facilities (Badan Pusat Statistik, 2019; Bank Indonesia \& Lembaga Pengembangan Perbankan Indonesia, 2015). Thus, a variety of Islamic FinTech services and products are expected to not only solve the problem of limited access of MSME but also the problem of managing business operations that are in line with sharia principles and as a form of efforts to achieve financial inclusion for MSME players (International Monetary Fund \& World Bank, 2019; PricewaterhouseCoopers, 2019) as the majority in Indonesian business ecosystem.

In the academic literature, research examining the specific intentions of MSME players in using Islamic FinTech products and services is still limited. Even so, there have been several studies examining the determinants of the intention to use Islamic FinTech, including the willingness to do transactions both for commercial or social motives using digital platforms. For social and donation purposes, Niswah, Mutmainah \& Legowati (2019), Sulaeman \& Ninglasari (2020), Aji et al. (2020), and Kasri \& Yuniar (2021) each of them examines the empirical factors that influence willingness to distribute zakat or donate sadaqah and infaq using digital platforms. The intention to donate cash waqf digitally was also investigated by Amin, Rahim, Ramayah \& Supinah (2014) and Kasri \& Chaerunnisa (2020). Meanwhile, research on the intention of using FinTech and digital platforms for commercial purposes was conducted by Shaikh, Qureshi \& Noordin (2020) and Thaker et al. (2019) examined the determinants factors of investment intention in FinTech P2P Lending Platform for Malaysian users.In more detail, Yuspita, Pebruary \& Kamala (2019), Darmansyah, Fianto, Hendratmi \& Aziz (2020) and Purwantini, Athief, \& Waharini (2020)empirically test the factors that influence the intention to use Islamic FinTech with the respondents from Indonesian people using Technology Acceptance Model TAM, Theory of Planned Behavior (TPB), and the unified theory of acceptance and use of technology (UTAUT) model. 
Majid The Role of Religiosity in Explaining the Intention to use Islamic FinTech Amongst MSME Actors

However, the previous research above has not yet tested empirically the intention of using Islamic FinTech to directly focus and target the segment of MSME actors as the majority of businesses in Indonesia, but still targeting the segment in general. In addition, the majority of previous studies have not integrated TAM, TPB, or UTAUT with other variables. On the basis of this, this study fills the gap in previous research by analyzing the factors that influence the intention to use Islamic FinTech by MSMEs using the Theory of TAM and TPB which are integrated with the variable of Religiosity of MSME actors towards the intention to use Islamic FinTech products and services.

\subsection{Objective}

This study aims to test empirically whether the Religiosity level affects the intention to use Islamic FinTech services and products. This paper starts with conducting a literature review on TAM, TPB, and decomposed theory of TPB followed by model construction based on previous research. Furthermore, the next section discusses the methodology and research model using PLSSEM and tested using the Smart-PLS tool. The next section is the results and analysis. This research closed with a conclusion, future research recommendation, and followed by limitations of this study.

\section{Literature Review}

\subsection{Background Theory}

\subsubsection{Technology Acceptance Model (TAM)}

TAM was introduced by Davis (1989) as an adaptation from Theory of Reasoned Action (TRA). Furthermore, TAM is expected to be able to predict individual attitudes and acceptance of technology and can provide the basic information needed regarding factors that motivate individual attitudes in accepting new technology (Venkatesh, Morris, Davis \& Davis, 2003; Venkatesh \& Bala, 2008).

There are two main factors that influence the adoption and use of technology by individuals. First, perceived usefulness namely the extent to which individuals believe that using IT will affect improving their job performance. Second, perceived ease of use namely the extent to which individuals believe that using IT will make it easy to get work done (Venkatesh \& Davis, 2000; Venkatesh \& Bala, 2008). 


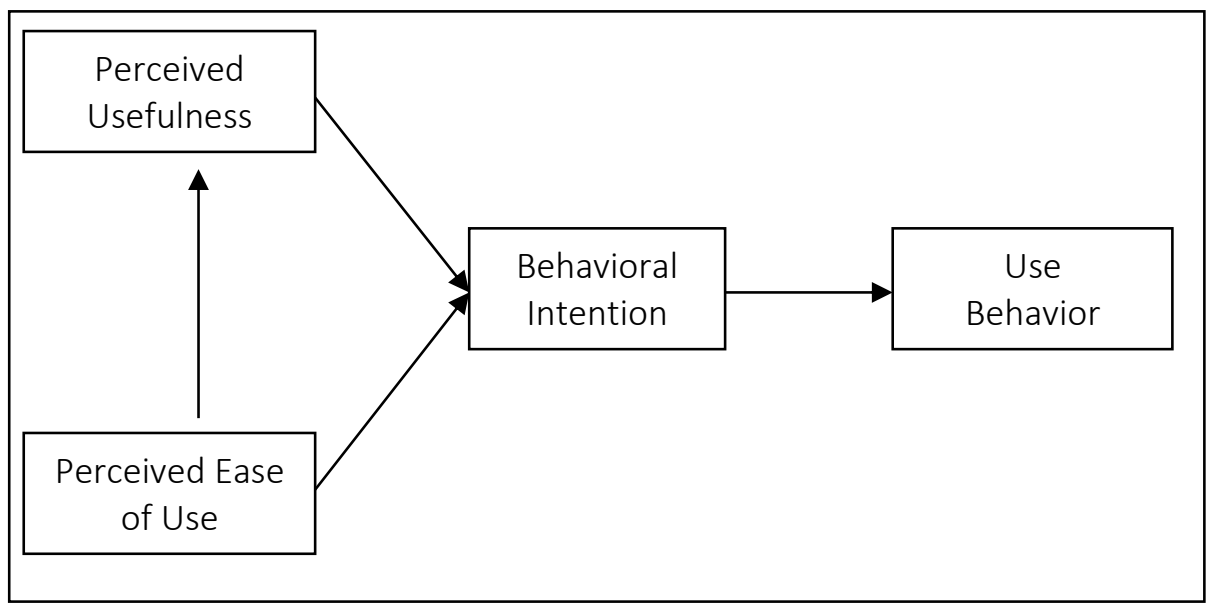

Figure 1. Theoritical Framework of TAM

Source: Venkatesh \& Bala (2008)

\subsubsection{Theory of Planned Behavior (TPB)}

TPB is a popular theory that is commonly used to know intentions in doing something that is developed by Icek Ajzen and Martin Fishbein (Ajzen \& Fisbhein, 1980). TPB is extended and developed from TRA, based on the assumption that humans generally behave wisely, take into account information and consider the implications for the actions taken (Ajzen, 2005). In TPB, the individual's intention to take an action/behavior is the main factor. The intention is assumed to capture the motivational factors that influence behavior. The stronger the intention to engage in an action, the greater the possibility of a given performance (Ajzen, 1991).

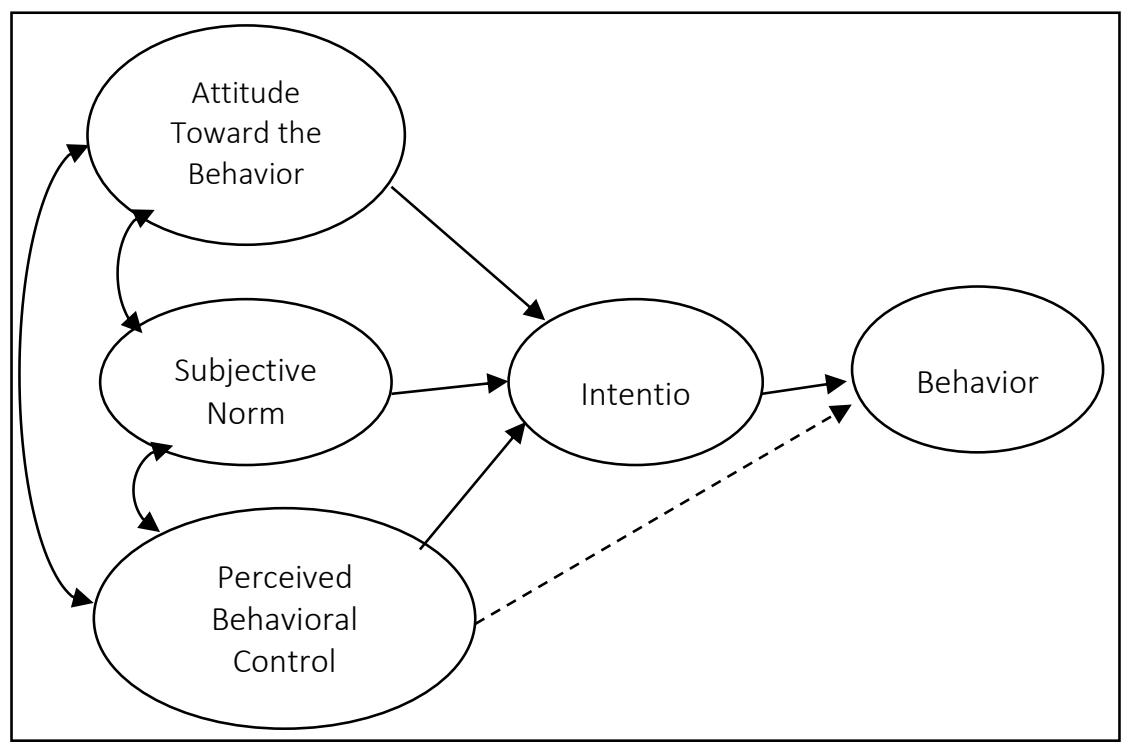

Figure 2. Theoritical Framework of TPB Source: (Ajzen, 1991) 
Majid | The Role of Religiosity in Explaining the Intention to use Islamic FinTech Amongst MSME Actors

Intention and behavior in TPB are a function of three basic determinants. First, personal in nature which is known as the term "Attitude Toward Behavior" (ATB). Secondly, a reflection of social influence (reflecting social influence) on the behavior to be carried out is known as the term "Subjective Norm" (SN). Thirdly, is related to control issues namely a sense of ease or difficulty or ability to carry out an action known as "Perceived Behavioral Control" (PBC) (Ajzen, 1991, 2005).

\subsubsection{The Decomposed Theory of Planned Behavior (TPB)}

This TPB decomposition model was introduced by Taylor \& Todd (1995) which refers to the construction of the characteristic innovation literature and more fully explores the dimensions of subjective norms (i.e. social influence) and perceived behavioral control (PBC) by breaking them down into certain belief dimensions. This decomposed TPB model has advantages similar to that of TAM in terms of identifying certain important beliefs that can influence the use of information technology (IT). According to this theory, IT usage behavior is actually influenced by intention, which in turn is also influenced by attitudes towards behavior (which are decomposed into perceived usefulness, perceived ease of use, and compatibility), subjective norms, and the influence of perceived behavioral control (Taylor \& Todd, 1995).

\subsection{Previous Studies}

Empirical research on the intention of using Islamic FinTech products and services is still very limited, especially by focusing on research on the intention of MSME actors as the backbone of the national economy. Darmansyah et al.(2020) comprehensively examine the intention of using Islamic FinTech society in general in Indonesia by using three competing models consist of the TAM, TPB, and The UTAUT. The results showed that the latent variables of TAM, TPB, and UTAUT have a significant impact on encouraging behavioral intentions using Islamic FinTech, where TAM latent variable is the most influential factor.

Ali, Raza, Khamis Puah \& Amin (2021) examined the determinants of the perceived benefit and the perceived risk of Islamic Fintech and the influence of the perceived benefit, perceived risk, and user trust on the intention to use Islamic FinTech to 321 respondents in Pakistan which was tested using SmartPLS. The results showed that the perceived benefit and perceived risk significantly influenced by their factors. Meanwhile, perceived risk had a negatively significant impact on trust. In addition, this study also finds 
empirically that there is a significant positive relationship between trust and intention to adopt Islamic Fintech.

Marzuki \& Nurdin (2020) was examined the influence of halal product expectation, social environment, and figh knowledge on intention to use Islamic FinTech products for 80 Muslim consumers who use sharia FinTech. The results of this research indicate that halal product expectations and knowledge about figh have significantly affect Indonesian Muslim consumers to use Islamic FinTech products. Meanwhile, the social environment shown through the representation of friends or well-known Muslim figures has no effect on the intention to use Islamic FinTech products.

Thaker, Amin, Thaker \& Pitchay (2019) examined the important factors that affected the intention to use Islamic mobile banking services by Malaysian Islamic banking users. Using primary data from a survey of 250 respondents, this research found that the continuance intention of using Islamic mobile banking services was affected by the usability, customer service, customer satisfaction, and trust of the customer. The same study was also conducted by Thaker, Thaker, Khaliq, Pitchay \& Hussain (2021) using a larger sample of 319 in the two main states in Malaysia, namely Kuala Lumpur and Selangor. By using UTAUT2, this study found that variables such as performance expectancy, effort expectancy, price value, facilitating conditions, and habit have a positive significant influence over the behavioral intention. Meanwhile, social influence and hedonic motivation were found negatively related and insignificant to behavioral intention. With a wider range of respondents, namely in Southeast Asia, Sun, Goh, Fam \& Xue (2012) explored the role of religious affiliation and commitment to adopt Islamic mobile phone banking. This study found that both religious affiliation and commitment were effective as segmentation strategies due to the difference in intention to adopt Islamic mobile phone banking were found between Muslim and non-Muslims, as well as devout.

Usman, Projo, Chairy \& Haque (2021) proposed an extended model of the TAM by including Sharia Compliance (SC), knowledge of SC, and confidence in $\mathrm{SC}$, then examine their effect on satisfaction in using e-banking of Indonesian Islamic banking. The results of this study indicate that SC, knowledge about SC, and belief in SC have a significant positive effect on customer satisfaction of e-banking intention of Indonesian Islamic Banking users. In addition, these three variables also have a significant to moderate the relationship between PU and PEOU on customer satisfaction. In addition, this study highlights the importance of sharia compliance in the extended TAM model.

Shaikh et al. (2020) in his research was examined the determinants of Bank Users in Malaysia to use Islamic FinTech service using the TAM approach. The 
Majid The Role of Religiosity in Explaining the Intention to use Islamic FinTech Amongst MSME Actors

results of this research on 205 respondents indicated that perceived ease of use, perceived usefulness, and consumer innovativeness $(\mathrm{Cl})$ were factors that influenced the intention to use Islamic FinTech in the Malaysian Context. On the other hand, self-efficacy and subjective norms have no effect on Islamic banking users' intention to use FinTech.

Based on the results of the previous research above, it is known that TAM and TPB indicators affect the intention to use Islamic FinTech. However, specifically, social influence and subjective norm were found to be influential in other studies, but also in some studies they were found to not affect. In several studies using the variable of sharia compliance knowledge or knowledge about figh, it was found that these variables were empirically proven to affect the intention to use Islamic FinTech. However, interestingly, there has been no research that specifically uses the religiosity variable as one of the determinants that affect the intention to use Islamic FinTech, especially for MSME actors.

\subsection{Rationalization of Theory and Hypothesis Development}

\subsubsection{Perceived Usefulness (PU) and Perceived Ease of Use (PEOU)}

In this study, ATB is described (decomposition) into perceived usefulness and perceived ease of use. PU tries to measure how the perception of people who use technology will improve their job performance. The intention to use Islamic FinTech is based on the benefits received by consumers (Darmansyah et al., 2020). In simply, If the consumer's view of services using FinTech is increasingly useful, then the general attitude towards using FinTech services will increase (Kim, Choi, Park, \& Yeon, 2016). In many empirical studies, it has been found that PU is consistently a strong determinant of intention to use information technology (Venkatesh \& Davis, 2000). In relation to the determinants of intention in using Islamic FinTech, PU includes specific relevant components. Darmansyah et al. (2020) found that PU, which is a component of TAM, has a significant positive effect on behavioral intention to use Islamic FinTech in Indonesia. The same resulted was stated by Niswah et al. (2019) that PU is a factor that encourages good acceptance of a technology system, especially in donating through FinTech. This means that using FinTech in donating is very beneficial because the donation process is faster, more effective, and easier, thereby increasing the interest in using FinTech.

H1: Perceived Usefullness (PU)of MSME actors effect on Attitude Toward Behavior (ATB) of using of Islamic FinTech

H2: Perceived Usefullness (PU)of MSME actors effect on Behavioral Intention

(BI) of using of Islamic FinTech 
Majid The Role of Religiosity in Explaining the Intention to use Islamic FinTech Amongst MSME Actors

Perceived Ease of Use (PEOU) influences the intention, perceived usefulness, attitude, and actualization of using technology (Davis, 1989). This means that the ease of use of technology will increase an individual's ability to use internet applications and services (Purwantini et al., 2020). Kazemi, Nilipour, Kabiry \& Hoseini (2013) in their research empirically found that all attributes related to innovation, namely the decomposition of PU and PEOU on ATB, had a significant effect on ATB. In this study, the easier the work done, the more benefits of using Islamic FinTech, the higher the behavior and intention of MSME actors to use Islamic FinTech.

H3: Perceived Ease of Use (PEOU) of MSME actors effect on Attitude Toward Behavior (ATB) of using of Islamic FinTech.

H4: Perceived Ease of Use (PEOU) of MSME actors effect on Behavioral Intention (BI)of using of Islamic FinTech.

\subsubsection{Attitude Towards Behavior}

Attitude towards behavior (ATB) refers to the extent to which a person has an evaluation or assessment of the likes or dislikes of the behavior being asked (Ajzen, 1991). ATB is a specific component that is relevant and has a positive and significant effect on the intention to use sharia-based FinTech as has been proven in previous studies. Kasri \& Chaerunnisa (2020) found that attitude toward behavior has a positive significant effect on the intention of millennials in Indonesia to donate cash money digitally. The same thing is also found in empirical research conducted by Yuspita et al. (2019) and Darmansyah et al. (2020) that tested people's perceptions of using FinTech services provided by Islamic financial institutions found that ATB has a positive influence.

H5: Attitude Toward Behavior (ATB) of MSME actors effect on the Intention of using Islamic FinTech.

\subsubsection{Subjective Norm}

Social factors in the form of subjective norms (SN) refer to the social pressure that is felt to do or not do a behavior. Generally, the more preferred subjective attitudes and norms, the greater the individual's intention to carry out the considered behavior (Ajzen, 1991). Darmansyah et al. (2020) in their research found that SN has a significant effect on the intention to use Islamic FinTech in Indonesia. The same thing is also found in the research of Jerene \& Sharma (2020) that subjective norms significantly positively affect the adoption of banking customers in Ethiopia to use FinTech services. Similarly, Kasri \& Chaerunnisa (2020) found a significant 
effect of subjective norms on millennial intentions to digitally to donate cash waqf.

H6: Subjective Norm (SN) of MSME actors effect on the Intention of using Islamic FinTech.

\subsubsection{Perceived Behavioral Control}

PBC refers to the perceived ease or difficulty in carrying out behavior and is assumed to reflect past experiences and the obstacles that have been anticipated. In general, the higher the behavior control, the higher the intention to do the desired action(Ajzen, 1991). PBC was found empirically to be the strongest factor influencing millennial intentions in Indonesia to donate cash waqf digitally (Kasri \& Chaerunnisa, 2020). Other than that, Darmansyah et al. (2020) in their research found that PBC has a significant positive effect on the intention to use Islamic FinTech in Indonesia.

H7: Perceived Behavioral Control (PBC) of MSME actors effect on the Intention of using Islamic FinTech.

\subsubsection{Religiosity}

Religiosity is the individual's ability to commit to religious beliefs by obeying what can and should not be done including values and practices in everyday life (Johan, Hussain, Mohd, \& Kamaruddin, 2020). In contemporary life, religion basically plays a significant ethical role in which the entire life it lives is shaped by divine law in religion. Ajzen \& Fishbein (1970)stated that attitude was found to be highly correlated with how much confidence in what aspects of evaluation a person believes. A person who has held a certain value of his religion will influence their actions and decisions in doing something (Alam, Janor, Zanariah, Wel, \& Ahsan, 2012). On this basis, commitment to religiosity is considered a relevant and strong determinant in shaping motivation and behavioral intention (Sun et al., 2012). Correspondingly, Alam et al. (2012)in their research found that religiosity is the most important factor and plays an important role in the intention to finance Islamic homes in Malaysia's Klang Valley. The same thing was found in research conducted by Kasri \& Chaerunnisa (2020)that religiosity is the most powerful factor affecting the intention to donate cash waqf digitally in Indonesia.

H8. Religiosity of MSME actors effect on the Intention of using Islamic FinTech. 
Majid The Role of Religiosity in Explaining the Intention to use Islamic FinTech Amongst MSME Actors

\section{Methodology}

\subsection{Data}

The data were obtained through filling out online questionnaires in Indonesian through google form which were answered directly by respondents. The qualifications of respondents in this study include MSME actors who have run business operations in Indonesia for at least two years and include as an active internet user as well as being able to operate Islamic FinTech platforms/applications and services. Respondents who do not meet the above requirements cannot fill out the research questionnaire. The questions in the questionnaire are divided into two parts, namely the demographics of the respondents and closed questions to measure the perceptions of MSME actors on the intention of using Islamic FinTech.

This study uses purposive sampling (judgement sampling), which is a sampling technique based on the characteristics assigned to the elements of the target population that are adjusted to the objectives or research problems. In this study, the respondents come from MSME actors who are the backbone of the national economy. MSMEs consists of micro, small and medium enterprises. Based on Law no. 20 year 2008 concerning Micro, Small and Medium Enterprises (MSMEs). Table 1 explains the difference among them.

Table 1. The Difference between Micro, Small, and Medium Enterprises

\begin{tabular}{lll}
\hline Type of Enterprises & \multicolumn{1}{c}{$\begin{array}{c}\text { Total of Assets } \\
\text { (excluding land and buildings) }\end{array}$} & Sales Results (per year) \\
\hline Micro Enterprises & Up to IDR 50 million & Up to IDR 300 million \\
Small Enterprises & IDR 50 million - IDR 500 million & $\begin{array}{l}\text { IDR } 300 \text { million - IDR 2,5 } \\
\text { billion }\end{array}$ \\
Medium Enterprises & IDR 500 million - IDR 10 billion & $\begin{array}{l}\text { IDR 2,5 billion - IDR } 50 \\
\text { billion }\end{array}$ \\
\hline
\end{tabular}

Source: Law No. 20 year 2008 of Republic of Indonesia (2008)

Table 2 shows the geographic information of respondents. A total of 100 samples were collected consisting of 54 micro-enterprises actors (54\%), 31 small-enterprises (31\%), and 15 medium-enterprises (15\%). Respondents did not only come from one location/region but consisted of all regional representatives in Indonesia who were from several major islands in Indonesia. The number of respondents in this study was considered enough for a research method using PLS-SEM due to PLS-SEM can be used for nonnormal data and small sample sizes (Hair, Sarstedt, Hopkins, \& Kuppelwieser, 2014; Hair, Sarstedt, Ringle, \& Mena, 2012; Khan et al., 2019). 
Majid The Role of Religiosity in Explaining the Intention to use Islamic FinTech Amongst MSME Actors

Table 2. Respondent Information Demographics

\begin{tabular}{|c|c|c|c|}
\hline Variable & Description & Frequency & Percentage \\
\hline \multirow[t]{2}{*}{ Sex } & Male & 80 & $80 \%$ \\
\hline & Female & 20 & $20 \%$ \\
\hline \multirow[t]{5}{*}{ Age } & $<20$ years old & 1 & $1 \%$ \\
\hline & 20-30 years old & 47 & $47 \%$ \\
\hline & 31-40 years old & 34 & $34 \%$ \\
\hline & 41-50 years old & 15 & $15 \%$ \\
\hline & >51 years old & 3 & $3 \%$ \\
\hline \multirow[t]{4}{*}{ Education } & Senior High school & 10 & $10 \%$ \\
\hline & Diploma & 11 & $11 \%$ \\
\hline & Bachelor Degree & 64 & $64 \%$ \\
\hline & Master Degree & 15 & $15 \%$ \\
\hline Business & Micro-Enterprises & 54 & $54 \%$ \\
\hline \multirow[t]{2}{*}{ Category } & Small-Enterprises & 31 & $31 \%$ \\
\hline & Medium-Enterprises & 15 & $15 \%$ \\
\hline Duration of & $1-5$ years & 73 & $73 \%$ \\
\hline Business & 5-10 years & 16 & $16 \%$ \\
\hline \multirow[t]{2}{*}{ Activity } & $10-20$ years & 10 & $10 \%$ \\
\hline & $>20$ years & 1 & $1 \%$ \\
\hline Business & Sumatera & 8 & $8 \%$ \\
\hline \multirow[t]{5}{*}{ Location } & Java & 81 & $81 \%$ \\
\hline & Nusa Tenggara-Bali & 1 & $1 \%$ \\
\hline & Sulawesi & 4 & $4 \%$ \\
\hline & Kalimantan & 5 & $5 \%$ \\
\hline & Maluku-Papua & 1 & $1 \%$ \\
\hline
\end{tabular}

Types of Islamic FinTech that respondents have used, both for social and commercial purposes, include Dana Syariah, Kitabisa.com, LinkAja Syariah, Global Sadaqah, Qazwa, Kapital Boost, Koperasi 212, Asy-Syirkah Muamalah Indonesia Cooperative, HSIP, Tamwyl, Ternaknesia, and the Dompet Madani.

\subsection{Model Development}

Study was adapted from previous relevant research topics which used the basic framework of TAM and TPB. Each variable is measured using a fivepoint Likert Scale to see respondents' opinions ranging from "Strongly Disagree" (Scale 1) to "Strongly Agree" (Scale 5). The majority of survey questions were adapted from research conducted by (Davis, 1989; Venkatesh \& Davis, 2000). Likewise, the construction of indicators on variables in TAM and TPB was adapted from research by (Davis, 1989; Pikkarainen, Pikkarainen, Karjaluoto \& Pahnila, 2004; Venkatesh \& Davis, 2000), while indicators in the Decomposed theory of planned behavior (TPB) were adapted from (Chuang, Liu, \& Kao, 2016; Taylor \& Todd, 1995). 
Majid The Role of Religiosity in Explaining the Intention to use Islamic FinTech Amongst MSME Actors

Meanwhile, the religiosity indicators is adapted from (Alam et al., 2012). All research questions have been adjusted based on the research topic. The kinds of variables and indicators used in this study are explained in Table 3.

Table 3. Measurement Items

\begin{tabular}{|c|c|c|}
\hline Construct & Indicator (s) & Source (s) \\
\hline \multirow[t]{4}{*}{ PU } & Accelerates the work/project & (Davis, 1989) \\
\hline & Makes the work more effective & $\begin{array}{l}\text { (Davis, 1989; Pikkarainen et al., 2004; } \\
\text { Venkatesh \& Davis, 2000) }\end{array}$ \\
\hline & Makes the work easier & (Davis, 1989; Pikkarainen et al., 2004) \\
\hline & Useful & $\begin{array}{l}\text { (Davis, 1989; Pikkarainen et al., 2004; Taylor } \\
\text { \& Todd, 1995; Venkatesh \& Davis, 2000) }\end{array}$ \\
\hline \multirow[t]{4}{*}{ PEOU } & Easy to learn & (Davis, 1989; Pikkarainen et al., 2004) \\
\hline & Clear and easy to understand & $\begin{array}{l}\text { (Davis, 1989; Pikkarainen et al., 2004; } \\
\text { Viswanath, Venkatesh \& Davis, 2000) }\end{array}$ \\
\hline & Flexible in use & (Davis, 1989; Pikkarainen et al., 2004) \\
\hline & Easy to use & $\begin{array}{l}\text { (Davis, 1989; Pikkarainen et al., 2004; Taylor } \\
\text { \& Todd, 1995; Viswanath, Venkatesh \& } \\
\text { Davis, 2000) }\end{array}$ \\
\hline \multirow[t]{3}{*}{ ATB } & Convenient to use & (Chuang et al., 2016; Taylor \& Todd, 1995) \\
\hline & Good ide to use it & (Chuang et al., 2016; Taylor \& Todd, 1995) \\
\hline & Like the idea of using & (Chuang et al., 2016; Taylor \& Todd, 1995) \\
\hline \multirow[t]{4}{*}{ SN } & $\begin{array}{l}\text { Influential people can influence } \\
\text { somenone's behavior }\end{array}$ & $\begin{array}{l}\text { (Alam et al., 2012; Davis, 1989; Viswanath, } \\
\text { Venkatesh \& Davis, 2000) }\end{array}$ \\
\hline & Important and meaningful & (Alam et al., 2012; Taylor \& Todd, 1995; \\
\hline & $\begin{array}{l}\text { people can influence } \\
\text { somenone's behavior }\end{array}$ & $\begin{array}{l}\text { Viswanath, Venkatesh \& Davis, 2000; } \\
\text { Viswanath Venkatesh \& Bala, 2008) }\end{array}$ \\
\hline & $\begin{array}{l}\text { People whose opinions are } \\
\text { important and strong can } \\
\text { influence someone's behavior }\end{array}$ & $\begin{array}{l}\text { (Alam et al., 2012; Taylor \& Todd, 1995; } \\
\text { Venkatesh \& Bala, 2008) }\end{array}$ \\
\hline \multirow[t]{3}{*}{ PBC } & Willingness to use & (Alam et al., 2012; Taylor \& Todd, 1995) \\
\hline & $\begin{array}{l}\text { Do the behavior without } \\
\text { coercion/compulsion }\end{array}$ & (Alam et al., 2012; Taylor \& Todd, 1995) \\
\hline & $\begin{array}{l}\text { There are available resources, } \\
\text { ability, and knowledge to use. }\end{array}$ & (Alam et al., 2012; Taylor \& Todd, 1995) \\
\hline \multirow[t]{6}{*}{ Religiosity } & Regularly to perform sholah & (Alam et al., 2012) \\
\hline & $\begin{array}{l}\text { Regularly perform fasting in the } \\
\text { holy month of Ramadan }\end{array}$ & (Alam et al., 2012) \\
\hline & Regularly read the holy Qur'an & (Alam et al., 2012) \\
\hline & $\begin{array}{l}\text { Follow the Islamic rules in } \\
\text { dailylife }\end{array}$ & (Alam et al., 2012) \\
\hline & Trying to avoid big and small sins & (Alam et al., 2012) \\
\hline & $\begin{array}{l}\text { Participation in the mosque in } \\
\text { order to increase Islamic } \\
\text { knowledge }\end{array}$ & (Alam et al., 2012) \\
\hline \multirow[t]{3}{*}{$\mathrm{BI}$} & Intention to use in near future & (Alam et al., 2012; Taylor \& Todd, 1995) \\
\hline & Intention to use & (Alam et al., 2012; Taylor \& Todd, 1995) \\
\hline & $\begin{array}{l}\text { Intention to using it repeatedly } \\
\text { (onwards) }\end{array}$ & (Alam et al., 2012; Taylor \& Todd, 1995) \\
\hline
\end{tabular}


The structural model (Figure 3) specifies the relationship between the exogenous and endogenous constructs. The structural model also answers how constructs are hypothesized to have mutual causality (Henseler, Hubona, \& Ray, 2016).

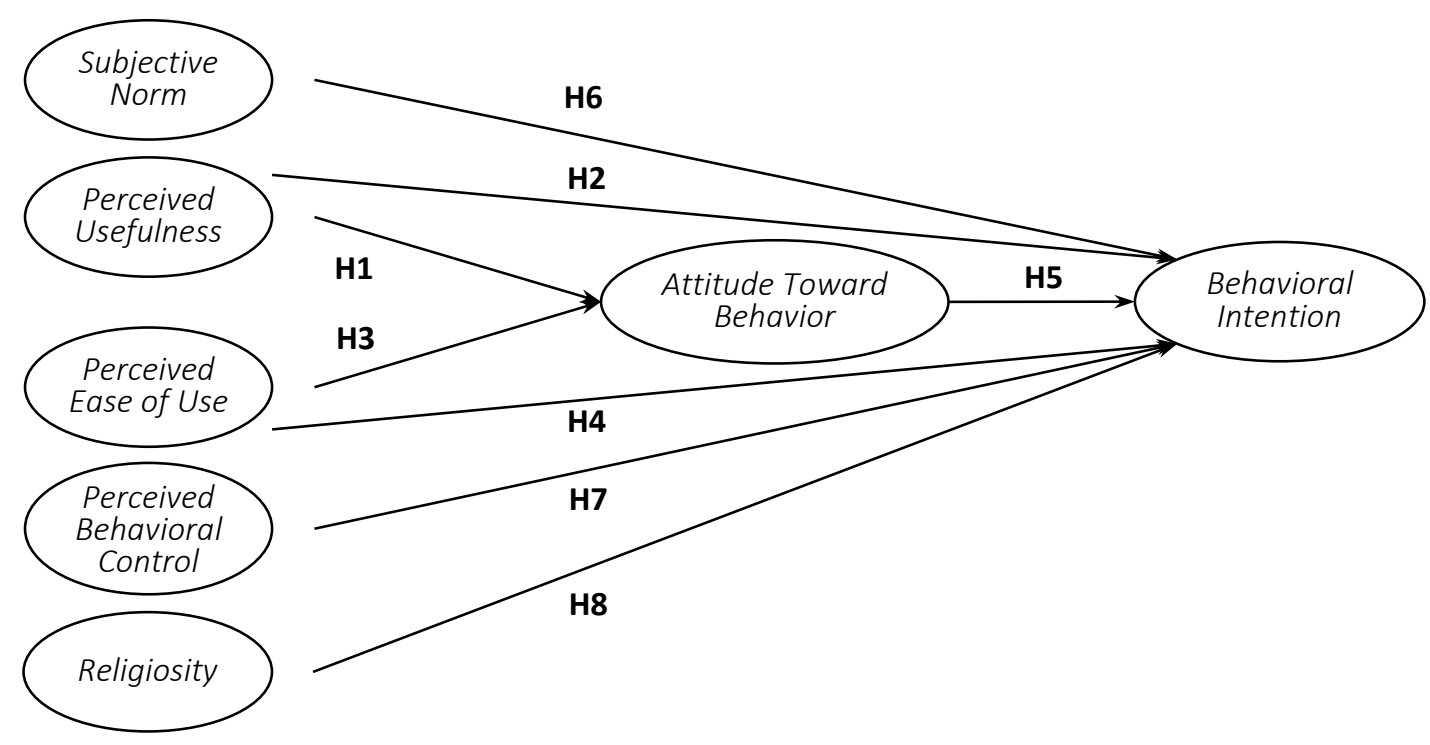

Figure 3. Research Model

\section{3 $\quad$ Method}

The research design used in this study is a quantitative approach. Measurement of research will be easier to understand with quantitative methods through filling out questionnaires by MSME actors as a tool to find out respondents' perceptions of the intention of using Islamic FinTech in carrying out their business operations. The research method used in this research isPartial Least Squares - Structural Equation Modelling (PLS-SEM).

PLS-SEM is a type of structural equation method based on variance, which is appropriate for explanative and predictive research (Hair et al., 2012). The author used PLS-SEM due to this method can accommodate a small number of samples/respondents as in this study. Hair et al. (2014) explained that the most prominent justifications for using PLS-SEM are attributed to three reasons namely non-normal data, small sample sizes, and type of constructs used are formative. In this study, the research model was tested using SmartPLS 3.0 software.

PLS-SEM can work effectively on the use of samples with small values even for complex models. PLS-SEMis conducted in two stages namely examination of the measurement model (outer model) and assessment of the structural model (inner model). The measurement models are used to evaluate and 
assess the relationship between the indicators of each variable used and their corresponding construct (Hair et al., 2014, 2012). This test consists of the validity and reliability test. The validity test itself comprised convergent and discriminant validity. This study uses factor loading (FL), Average Variance Extracted (AVE), Cronbach's alpha values and Composite Reliability (CR) to assess convergent validity. The FLs and AVE values are greater than or equal to 0.5, while the recommended CR and Cronbach's Alpha values are greater than or equal to 0.7 (Hair et al., 2014).

Testing on structural models is assessed based on the R-Square (R2) value which indicates a goodness-fit test model. The R2 value explains how many exogenous variables in the model are possible to explain endogenous variables. The higher R2 value indicates the better of the model in the study.

\section{Results and Analysis}

\subsection{Result}

\subsubsection{Measurement Model}

Table 4. Analysis of Factor on All Measurement Items

\begin{tabular}{|c|c|c|c|c|c|}
\hline Constructs & Items & $\mathrm{FL}$ & $\alpha$ & $\mathrm{CR}$ & AVE \\
\hline \multirow{3}{*}{ Subjective Norm } & SN1 & 0,862 & \multirow{3}{*}{0,737} & \multirow{3}{*}{0,852} & \multirow{3}{*}{0,660} \\
\hline & SN2 & 0,848 & & & \\
\hline & SN3 & 0,719 & & & \\
\hline \multirow{3}{*}{ Perceived Behavioral control } & PBC1 & 0,901 & \multirow{3}{*}{0,839} & \multirow{3}{*}{0,903} & \multirow{3}{*}{0,757} \\
\hline & PBC2 & 0,884 & & & \\
\hline & PBC3 & 0,824 & & & \\
\hline \multirow{4}{*}{ Perceived Usefullness } & PU1 & 0,934 & \multirow{4}{*}{0,955} & \multirow{4}{*}{0,968} & \multirow{4}{*}{0,882} \\
\hline & PU2 & 0,958 & & & \\
\hline & PU3 & 0,929 & & & \\
\hline & PU4 & 0,936 & & & \\
\hline \multirow{4}{*}{ Perceived Ease of Use } & PEOU1 & 0,840 & \multirow{4}{*}{0,856} & \multirow{4}{*}{0,902} & \multirow{4}{*}{0,698} \\
\hline & PEOU2 & 0,816 & & & \\
\hline & PEOU3 & 0,792 & & & \\
\hline & PEOU4 & 0,891 & & & \\
\hline \multirow{3}{*}{ Attitude Toward Behavior } & ATB1 & 0,794 & \multirow{3}{*}{0,783} & \multirow{3}{*}{0,873} & \multirow{3}{*}{0,697} \\
\hline & ATB2 & 0,875 & & & \\
\hline & ATB3 & 0,834 & & & \\
\hline \multirow{6}{*}{ Religiosity } & R1 & 0,896 & \multirow{6}{*}{0,950} & \multirow{6}{*}{0,959} & \multirow{6}{*}{0,798} \\
\hline & $\mathrm{R} 2$ & 0,903 & & & \\
\hline & R3 & 0,884 & & & \\
\hline & R4 & 0,876 & & & \\
\hline & R5 & 0,918 & & & \\
\hline & R6 & 0,882 & & & \\
\hline \multirow{4}{*}{ Behavioral Intention } & $\mathrm{Bl} 1$ & 0,898 & \multirow{4}{*}{0,938} & \multirow{4}{*}{0,956} & \multirow{4}{*}{0,844} \\
\hline & $\mathrm{B} 12$ & 0,939 & & & \\
\hline & $\mathrm{BI3}$ & 0,934 & & & \\
\hline & $\mathrm{B} \mid 4$ & 0,903 & & & \\
\hline
\end{tabular}


Majid The Role of Religiosity in Explaining the Intention to use Islamic FinTech Amongst MSME Actors

Based on testing on convergent validity, all items meet the required value. FL and AVE values support convergent validity and so do CR and Cronbach's alpha values which also support the reliability of each question item. This can be seen from Table 4 which the value of CR (>0.70), Cronbach's alpha ( $\alpha>$ 0.70), LF (> 0.50), and AVE (> 0.50) i which were more than the recommended value.

\subsubsection{Structural Model}

The value of R2 is the determinant coefficient in the construct of endogenous variables, namely Attitude Toward Behavior (ATB) and Behavioral Intention (BI) in this study.

Table 5. R-Square $\left(R^{2}\right)$ Test Results

\begin{tabular}{lll}
\hline & R-Square & R-Square Adjusted \\
\hline ATB & 0,653 & 0,646 \\
BI & 0,655 & 0,633 \\
\hline
\end{tabular}

Based on the table above, it is showed that ATB has an $R^{2}$ value of 0.653 which means that ATB is an endogenous variable that can be explained by the exogenous variables, namely PU and PEOU of $65.3 \%$, and the remaining $34.7 \%$ is explained by other variables outside of the model. Another result showed that $\mathrm{BI}$ has $\mathrm{R}^{2}$ of 0.655 which means that the endogenous variables of $\mathrm{BI}$ can be explained by exogenous variables, namely: SN, ATU, PU, PEOU, PBC, and Religiosity of $65.5 \%$, and the remaining $34.5 \%$ is explained by other variables outside of the model. This shows that the research model is considered good.

Based on the results of statistical tests using bootstrapping analysis, it was found that 6 out of 8 hypotheses had a significant effect. In table 5 , it can be seen that $\mathrm{H} 5$ and $\mathrm{H} 7$ have a $\mathrm{P}$-value that is more than 0.05 so that attitude toward behavior (ATB) and perceived behavioral control (PBC) have no significant impact on the intention to use sharia FinTech. Meanwhile, $\mathrm{H} 1, \mathrm{H} 2$, $\mathrm{H} 3$, and $\mathrm{H} 6$ empirically have a significant effect on the model at $5 \%$ alpha, while $\mathrm{H} 4$ and $\mathrm{H} 8$ have a significant effect on alpha $10 \%$, it can be seen in Table 6. 
Majid The Role of Religiosity in Explaining the Intention to use Islamic FinTech Amongst MSME Actors

Table 6. Direct relation of Structural Model

\begin{tabular}{lllll}
\hline Hipotesis & Original Sample & T-statistics & P-Values & Result \\
\hline $\mathrm{H} 1: \mathrm{PU} \rightarrow \mathrm{ATB}$ & 0,371 & 3,131 & $0,002^{*}$ & Supported \\
$\mathrm{H} 2: \mathrm{PU} \rightarrow \mathrm{BI}$ & 0,309 & 3,154 & $0,002^{*}$ & Supported \\
$\mathrm{H} 3: \mathrm{PEOU} \rightarrow \mathrm{ATB}$ & 0,519 & 5,671 & $0,000^{*}$ & Supported \\
$\mathrm{H} 4: \mathrm{PEOU} \rightarrow \mathrm{BI}$ & $-0,187$ & 1,721 & $0,086^{*}$ & Supported \\
$\mathrm{H} 5: \mathrm{ATB} \rightarrow \mathrm{BI}$ & 0,195 & 1,496 & 0,135 & Not Supported \\
$\mathrm{H} 6: \mathrm{SN} \rightarrow \mathrm{BI}$ & 0,453 & 5,579 & $0,000^{*}$ & Supported \\
$\mathrm{H} 7: \mathrm{PBC} \rightarrow \mathrm{BI}$ & 0,082 & 0,933 & 0,351 & Not Supported \\
$\mathrm{H} 8: \mathrm{R} \rightarrow \mathrm{BI}$ & 0,106 & 1,695 & $0,091^{* *}$ & Supported \\
\hline \multicolumn{4}{c}{ Note. * Significant at level 1\%, $\%$ Significant at level 10\% }
\end{tabular}

Note: *Significant at level 1\%, **Significant at level 10\%

\subsection{Analysis}

Based on the findings, Perceived usefulness (PU) has a significant impactboth on the will (attitude toward behavior) and behavioral intention to use Islamic FinTech by MSME players. This means that the presence of Islamic FinTech provides convenience in accelerating the completion of MSME business operations, is not only limited to a will/action but is followed by inclusiveness to use FinTech services and products. For example, Islamic FinTech categorized as the peer-to-peer lending such as Dana Syariah, Dompet Madani, and Ternaknesia can be an alternative to new financing schemes outside banking that can help resolve MSMEs capital constraints so that business expansion can be carried out. In addition, the presence of FinTech categorized as digital financial innovations can be a solution of payment, especially for commercial business activities like payment for water, electricity, telephone, pulses, and so on, also helps complete daily, weekly or monthly MSME business operational. These results are also consistent with the previous studies conducted by (Chuang et al., 2016; Darmansyah et al., 2020; Jerene \& Sharma, 2020; Purwantini et al., 2020; Shaikh et al., 2020).

Perceived Ease of Use (PEOU) of MSME actors also has a significant influence both on the will/action (Attitude Toward Behavior) as well as behavioral intention to use Islamic FinTech. This means that ease of daily transaction payments, the effectiveness of transaction settlement, both for internal MSMEs, or those involving consumers and third parties are the driving force for using Islamic FinTech such as easy access that makes user friendly to donate or pay company zakat or employees through the FinTech platform. These results also support the previous studies by (Amin et al., 2014; Chuang et al., 2016; Darmansyah et al., 2020; Niswah et al., 2019; Purwantini et al., 2020; Shaikh et al., 2020)

The next result shows that Attitude Toward Behavior (ATU) and Perceived Behavioral Control (PBC) both do not affect the intention of using Islamic 
FinTech by MSME actors. This shows that the services provided by Islamic FinTech to accelerate business operations of MSMEs are still limited to a willingness and has not been continued as an intention to adopt it. This may be due to the high literacy of Islamic FinTech but it has not been accompanied by Islamic financial inclusion. This may due to the presence of Islamic FinTech as an alternative source of financing for MSMEs is still yet no effect on the intention of MSME players to use it. There are many MSME players who still use other types of financing, both from conventional financial institutions or individual capital. This finding is in line with the results of research by Kim et al. (2016) that excessive attention to the privacy of the information on FinTech services types of payment has a negative effect on usage intentions, where it diverts people to donate directly to the intended community without going through FinTech. In addition, problems such as fraud, hacking, identity theft, and other cybercrimes are also the main reasons that reduce the trust of many people to use FinTech (Niswah et al., 2019). However, this study supports the result of a previous study conducted by (Niswah et al., 2019; Purwantini et al., 2020) and contrasts to research findings by Yuspita et al. (2019).

Subjective Norm (SN) has a significant influence on the intention of using Islamic FinTech by MSMEs. This finding indicates that important figures, business environment such as work partners, employees of MSME actors also support and provide recommendations to use Islamic FinTech services and products. Further, encouragement and recommendations from these influential people will affect MSME actors to use FinTech to make donations and/or use other Islamic FinTech features. This finding is in line with the previous research by (Darmansyah et al., 2020; Jerene \& Sharma, 2020; Kasri \& Chaerunnisa, 2020; Kim et al., 2016; Niswah et al., 2019).

The important role of religiosity level in influencing the behavioral intention of MSME acts to use Islamic FinTech services and products, which is in line with the last hypothesis, shows that there is a positive and significant relationship between the variables. These results indicate that the higher the level of religiosity of MSME actors, the more they will encourage their intention to use Islamic FinTech. Almost all respondents believe that using Islamic FinTech will bring more blessings in running their business. This is because for them by using Islamic FinTech products and services, it means that they have tried to follow Islamic rules in gathering and trying to avoid prohibited transactions such as riba, gharar, and maysir, especially in terms of the need for venture capital, investment, and other financing schemes. These results indicate that religiosity is a shield for an individual to commit to what he believes in an act whether it is permissible or not based on what has been outlined by religion(Johan et al., 2020). In addition, religiosity is the main drivers to attract intention in case of using new or 
Majid The Role of Religiosity in Explaining the Intention to use Islamic FinTech Amongst MSME Actors

novel products (Ateeq-ur-Rehman \& Shabbir, 2010; Mansori, Sambasivan, \& Md-Sidin, 2015). Thus, highlighting the religious aspect can encourage more participation of MSME actors to interact with Islamic FinTech products and services. This finding is also in line with those of some previous studies conducted by (Amin et al., 2014; Kasri \& Chaerunnisa, 2020).

\section{Conclusion and Recommendation}

\subsection{Conclusion}

This study examined to analyze the factors that influence the intention of MSME actors to use Islamic FinTech by integrating both TAM and TPB approach as well as the role of religiosity in the conceptual model. Based on the results, this research found that both PU and PEOU are significant influence both on the attitude toward behavior (ATB) and also behavioral intention (BI) of using Islamic FinTech services. However, ATB and PBC were found to have no significant effect on the intention to use Islamic FinTech by MSME actors. The main findings suggest that religiosity plays an important role in explaining the behavioral intention of using Islamic FinTech by MSME actors. Furthermore, Subjective norm is found to be empirically influential on $\mathrm{BI}$ and is the strongest influential determinant factor under the TPB framework of using Islamic FinTech.

\subsection{Recommendations}

Based on the results and analyzes, it is suggested that the regulator of FinTech institutions namely the Financial Service Authority (OJK) can do more collaborate with the Indonesian Islamic FinTech Association (AFSI) and the FinTech institutions themselves to increase socialization and literacy regarding services, types of products, the advantages of features and security as well as report transparency, as well as other things that can increase the inclusiveness of MSME players, especially in terms of fulfilling access to finance and accelerating the resolution of business operational challenges. Increasing literacy, providing incentives, strengthening consumer data protection, and making transactions easier using Islamic FinTech. In particular, Islamic FinTech institutions can incorporate religious values that contain guidelines and strategies in doing business to achieve blessings. In addition, literacy regarding the types of transactions that are prohibited, such as riba, gharar, and maysir which is a sin if done can be included in the display and content of platforms or social media as well as messages, whether in the form of quotations from the Qur'an, hadith, the words of Islamic scholars, and influential figures. 
Majid The Role of Religiosity in Explaining the Intention to use Islamic FinTech Amongst MSME Actors

This study has limitations in the case of the limited number of samples. In addition, the majority of the sample is concentrated on Java Island, which in terms of access to information disclosure is much better than in non-Java areas. Thus, it is hoped that the next research can increase the sample size capacity of each type of business (micro, small, and medium) and the wider distribution area of respondents. Subsequent research is also suggested to use and combine the model development by integrating the variable of sharia-compliant knowledge, either as an independent variable or as a mediating variable.

\section{Acknowledgements}

The author is grateful to Lembaga Pengelola Dana Pendidikan (LPDP) ministry of Finance for sponsoring my master's study in Islamic Economics Science, Faculty of Economics and Business, Airlangga University as well as fully supporting me to complete this research. 
Majid The Role of Religiosity in Explaining the Intention to use Islamic FinTech Amongst MSME Actors

\section{References}

Aaron, M., Rivadeneyra, F., \& Sohal, S. (2017). Fintech: Is this time different? A Framework for Assessing Risks and Opportunities for Central Banks (No. ISSN 1914-0568 2). Bank of Canada Staff Discussion Paper (Vol. No. 2017-1).

Aji, H. M., Albari, A., Muthohar, M., Sumadi, S., Sigit, M., Muslichah, I., \& Hidayat, A. (2020). Investigating the determinants of online infaq intention during the COVID-19 pandemic: An insight from Indonesia. Journal of Islamic Accounting and Business Research, 12(1), 1-20. doi:10.1108/JIABR-05-2020-0136

Ajzen, I. (1991). The theory of planned behavior. Organizational Behavior and Human Decision Processes, 50, 179-211.

Ajzen, I. (2005). Attitudes, personality and behavior. Berkshire, England SL6 2QL: Open University Press.

Ajzen, I., \& Fisbhein, M. (1980). Understanding attitudes and predicting social behaviour. Englewood Cliffs, NJ.: PrenticeHall.

Ajzen, I., \& Fishbein, M. (1970). The prediction of behavior from attitudinal and normative variables. Journal of Experimental Social Psychology, 6(4), 466-487. doi:10.1016/0022-1031(70)90057-0

Alam, S. S., Janor, H., Zanariah, Wel, C. A. C., \& Ahsan, M. N. (2012). Is Religiosity an important factor in influencing the intention to undertake Islamic home financing in Klang Valley?. World Applied Sciences Journal, 19(7), 1030-1041. doi:10.5829/idosi.wasj.2012.19.07.392

Ali, M., Raza, S. A., Khamis, B., Puah, C. H., \& Amin, H. (2021). How perceived risk, benefit and trust determine user fintech adoption: A new dimension for Islamic finance. Foresight, ahead-of-p(September 2020), ahead-of-print. doi:10.1108/FS-09-2020-0095

Amin, H., Rahim, A., Ramayah, T., \& Supinah, R. (2014). Determinants of online waqf acceptance: An empirical investigation. EJISDC: The Electronic Journal on Information Systems in Developing Countries, 60(8), 1-18. doi:10.1002/j.1681-4835.2014.tb00429.x

Ateeq-ur-Rehman, \& Shabbir, M. S. (2010). The relationship between religiosity and new product adoption. Journal of Islamic Marketing, 1(1), 63-69. doi:10.1108/17590831011026231

Badan Pusat Statistik. (2019). Analisis hasil SE2016 lanjutan: Potensi peningkatan kinerja usaha mikro kecil. Jakarta: Badan Pusat Statistik.

Bank Indonesia, \& LPPI. (2015). Profil bisnis usaha mikro, kecil dan menengah (UMKM). Jakarta: Bank Indonesia.

Chemmanur, T. J., Imerman, M. B., Rajaiya, H., \& Yu, Q. (2020). Recent developments in the fintech industry. Journal of Financial Management, 
Majid The Role of Religiosity in Explaining the Intention to use Islamic FinTech Amongst MSME Actors

Markets and Institutions, 08(01), 1-31. doi: 10.1142/s2282717x20400022

Chuang, L.-M., Liu, C.-C., \& Kao, H.-K. (2016). The adoption of fintech service: TAM perspective. International Journal of Management and Administrative Sciences (IJMAS), 3(07), 1-15. Retrieved from www.ijmas.orgwww.ijmas.org

Darmansyah, Fianto, B. A., Hendratmi, A., \& Aziz, P. F. (2020). Factors determining behavioral intentions to use Islamic financial technology: Three competing models. Journal of Islamic Marketing, ahead-ofp(ahead-of-print). doi:10.1108/JIMA-12-2019-0252

Davis, F. D. (1989). Perceived usefulness, perceived ease of use, and user acceptance of information technology. MIS Quarterly: Management Information Systems, 13(3), 319-340. doi:10.2307/249008

DinarStandard. (2021). Global Islamic fintech report 2021. Retrieved from https://cdn.salaamgateway.com/reports/pdf/6127a0965afd7898a34f6 9dadc24b8d17ada0b1b.pdf

DSN-MUI. (2018). Fatwa Dewan syariah nasional-majelis ulama Indonesia No: 117/DSN-MUI/II/2018 Tentang Layanan Pembiayaan Berbasis Teknologi Informasi Berdasarkan Prinsip Syariah. Jakarta: Dewan Syariah Nasional Majelis Ulama Indonesia.

Fenwick, M., McCahery, J. A., \& Vermeulen, E. P. M. (2017). Fintech and the financing of entrepreneurs: From crowdfunding to marketplace lending. The Economics of Crowdfunding: Startups, Portals and Investor Behavior. doi: 10.1007/978-3-319-66119-3_6

Hair, J. F., Sarstedt, M., Hopkins, L., \& Kuppelwieser, V. G. (2014). Partial least squares structural equation modeling (PLS-SEM): An emerging tool in business research. European Business Review, 26(2), 106-121. doi:10.1108/EBR-10-2013-0128

Hair, J. F., Sarstedt, M., Ringle, C. M., \& Mena, J. A. (2012). An assessment of the use of partial least squares structural equation modeling in marketing research. Journal of the Academy of Marketing Science, 40(3), 414-433. doi:10.1007/s11747-011-0261-6

Henseler, J., Hubona, G.S. \& Ray, P.A. (2016). Using PLS path modeling in new technology research: updated guidelines, Industrial Management and Data Systems, 116 (1), 1-19

IMF, \& World Bank. (2019). Fintech: The experience so far. IMF Policy Paper, (June), 1-77. Retrieved from https://www.imf.org/ /media/Files/Publications/PP/2019/PPEA201902 4.ashx

Jerene, W., \& Sharma, D. (2020). The adoption of financial technology in Ethiopia: a study of bank customers perspective. Journal of Banking and Financial Technology, 4(1), 53-63. doi:10.1007/s42786-020-00015-0 
Majid The Role of Religiosity in Explaining the Intention to use Islamic FinTech Amongst MSME Actors

Johan, Z. J., Hussain, M. Z., Mohd, R., \& Kamaruddin, B. H. (2020). Muslims and non-Muslims intention to hold Shariah-compliant credit cards: a SmartPLS approach. Journal of Islamic Marketing, ahead-of-p(ahead-ofprint). doi:10.1108/JIMA-12-2019-0270

Kasri, R. A., \& Chaerunnisa, S. R. (2020). The role of knowledge, trust, and religiosity in explaining the online cash waqf amongst Muslim millennials. Journal of Islamic Marketing, ahead-of-p(ahead-of-print). doi:10.1108/JIMA-04-2020-0101

Kasri, R. A., \& Yuniar, A. M. (2021). Determinants of digital zakat payments: Lessons from Indonesian experience. Journal of Islamic Accounting and Business Research, ahead-of-p(ahead-of-print). doi:10.1108/JIABR-082020-0258

Kazemi, D. A., Nilipour, D. A., Kabiry, N., \& Hoseini, M. M. (2013). Factors affecting isfahanian mobile banking adoption based on the decomposed theory of planned behavior. International Journal of Academic Research in Business and Social Sciences, 3(7), 230-245. doi:10.6007/ijarbss/v3-i7/29

Kemenkopukm. (2018). Perkembangan data usaha mikro, kecil, dan menengah (UMKM) dan usaha besar (UB) Tahun 2018-2019. Retrieved 28 April 2021, from https://www.kemenkopukm.go.id/uploads/laporan/1617162002_SAND INGAN_DATA_UMKM_2018-2019.pdf

Khan, G. F., Sarstedt, M., Shiau, W. L., Hair, J. F., Ringle, C. M., \& Fritze, M. P. (2019). Methodological research on partial least squares structural equation modeling (PLS-SEM): An analysis based on social network approaches. Internet Research, 29(3), 407-429. doi:10.1108/IntR-122017-0509

Kim, Y., Choi, J., Park, Y. J., \& Yeon, J. (2016). The adoption of mobile payment services for "fintech". International Journal of Applied Engineering Research, 11(2), 1058-1061.

Law No. 20 year 2008. (2008). Law No. 20 year 2008 concerning Micro, Small and Medium Enterprises (MSMEs). LN.2008/NO.93, TLN NO.4866, LL SETNEG : $20 \mathrm{HLM}$. Sekretaris Negara Republik Indonesia. Retrieved from https://peraturan.bpk.go.id/Home/Details/39653/uu-no-20tahun-2008

Mansori, S., Sambasivan, M., \& Md-Sidin, S. (2015). Acceptance of novel products: The role of religiosity, ethnicity and values. Marketing Intelligence and Planning, 33(1), 39-66. doi:10.1108/MIP-03-2013-0050

Marzuki, M., \& Nurdin, N. (2020). The influence of halal product expectation, social environment, and fiqih knowledge on intention to use shariah financial technology products. International Journal of Innovation, Creativity and Change, 13(1), 171-193.

Niswah, F. M., Mutmainah, L., \& Legowati, D. A. (2019). Muslim millennial's 
Majid The Role of Religiosity in Explaining the Intention to use Islamic FinTech Amongst MSME Actors

intention of donating for charity using fintech platform. Journal of Islamic Monetary Economics and Finance, 5(3), 623-644. doi: 10.21098/jimf.v5i3.1080

Pew Research Center. (2011). Muslim population growth by country. Retrieved $28 \quad$ April 2021, from https://www.pewforum.org/2011/01/27/table-muslim-populationgrowth-by-country/

Pikkarainen, T., Pikkarainen, K., Karjaluoto, H., \& Pahnila, S. (2004). Consumer acceptance of online banking: An extension of the technology acceptance model. Internet Research, 14(3), 224-235. doi:10.1108/10662240410542652

Purwantini, A. H., Athief, F. H. N., \& Waharini, F. M. (2020). Indonesian consumers' intention of adopting Islamic financial technology services. Shirkah, 5(2), 171-196.

PwC. (2019). Indonesia's fintech lending: Driving Economic growth through financial inclusion. PwC Indonesia - Fintech Series. Retrieved from https://www.pwc.com/id/en/fintech/PwC_FintechLendingThoughtLead ership_ExecutiveSummary.pdf

Shaikh, I. M., Qureshi, M. A., \& Noordin, K. (2020). Acceptance of islamic financial technology (fintech) banking services by Malaysian users: An extension of technology acceptance model. Foresight, 22(3), 367-383. doi:https://doi.org/10.1108/FS-12-2019-0105

Sulaeman, S., \& Ninglasari, S. Y. (2020). Analyzing the behavioral intention factors in using zakat-based crowdfunding platform in Indonesia. International Journal of Zakat, 5(3), 1-19. doi:10.37706/ijaz.v5i3.267

Sun, S., Goh, T., Fam, K. S., \& Xue, Y. (2012). The influence of religion on Islamic mobile phone banking services adoption. Journal of Islamic Marketing, 3(1), 81-98. doi:10.1108/17590831211206617

Taylor, S., \& Todd, P. A. (1995). Understanding information technology usage: A test of competing models author. Information Systems Research, 6(2), 144-176.

Thaker, M. A. B. M. T., Amin, M. F. Bin, Mohd Thas Thaker, H. Bin, \& Allah Pitchay, A. Bin. (2019). What keeps Islamic mobile banking customers loyal? Journal of Islamic Marketing, 10(2), 525-542. doi:10.1108/JIMA08-2017-0090

Thaker, M. A. B. M. T., Thaker, H. B. M. T., Rahman, M. P. B., Amin, M. F. Bin, Pitchay, A. B. A., \& Olaniyi, N. O. (2019). Factors affecting investors' intention to invest in a peer-to-peer lending platform in malaysia: an extended technology acceptance model. Tokyo. Retrieved from available: $\quad$ https://www.adb.org/publications/factors-affectinginvestors-intention-invest-peer-peer- lending-platform-malaysia

Thaker, M. T. H., Thaker, M. T. M. A., Khaliq, A., Pitchay, A. A., \& Hussain, I. H. 
Majid | The Role of Religiosity in Explaining the Intention to use Islamic FinTech Amongst MSME Actors

(2021). Behavioural intention and adoption of internet banking among clients' of Islamic banks in Malaysia: an analysis using UTAUT2. Journal of Islamic Marketing, ahead-of-p(ahead-of-print). doi:10.1108/JIMA-112019-0228

The World Bank. (2020). Leveraging Islamic Fintech to improve financial inclusion. Kuala Lumpur, Malaysia. https://doi.org/10.1596/34520

Usman, H., Projo, N. W. K., Chairy, C., \& Haque, M. G. (2021). The exploration role of Sharia compliance in technology acceptance model for ebanking (case: Islamic bank in Indonesia). Journal of Islamic Marketing, ahead-of-p(ahead-of-print). doi:10.1108/JIMA-08-2020-0230

Venkatesh, Viswanath, , \& Davis, F. D. (2000). A theoretical extension of the technology acceptance model: Four longitudinal field studies. Management Science, 46 (2) (May 2014), 186-204. Retrieved from https://www.jstor.org/stable/2634758

Venkatesh, Viswanath, \& Bala, H. (2008). Technology acceptance model 3 and a research agenda on interventions. Decision Sciences, 39(2), 273315. doi:10.1111/j.1540-5915.2008.00192.x

Venkatesh, Viswanath, Morris, M. G., Davis, G. B., \& Davis, F. D. (2003). User acceptance of information technology: Toward a unified view. MIS Quarterly: Management Information Systems, 27(3), 425-478.

Yuspita, R., Pebruary, S., \& Kamala, A. Z. H. (2019). The society's perceptions on the use of fintech services in sharia financial institutions. Jurnal Ekonomi \& Keuangan Islam, 5(2), 87-92. doi:10.20885/jeki.vol5.iss2.art6 
Majid | The Role of Religiosity in Explaining the Intention to use Islamic FinTech Amongst MSME Actors

This page is intentionally left blank.

International Journal of Islamic Economics and Finance (IJIEF), 4(2), 207-232 | 232 